5-1-2015

\title{
The Process of Othering from the "Social Imaginaire" to Physical Acts: An Anthropological Approach
}

Anthonie Holslag

University of Amsterdam

Follow this and additional works at: https://digitalcommons.usf.edu/gsp

\section{Recommended Citation}

Holslag, Anthonie (2015) "The Process of Othering from the "Social Imaginaire" to Physical Acts: An Anthropological Approach," Genocide Studies and Prevention: An International Journal: Vol. 9: Iss. 1:

96-113.

DOI:

http://dx.doi.org/10.5038/1911-9933.9.1.1290

Available at: https://digitalcommons.usf.edu/gsp/vol9/iss1/10

This Articles is brought to you for free and open access by the Open Access Journals at Digital Commons @ University of South Florida. It has been accepted for inclusion in Genocide Studies and Prevention: An International Journal by an authorized editor of Digital Commons @ University of South Florida. For more information, please contact digitalcommons@usf.edu. 


\title{
The Process of Othering from the "Social Imaginaire" to Physical Acts: An Anthropological Approach
}

\author{
Anthonie Holslag \\ University of Amsterdam \\ Amsterdam, Netherlands
}

\begin{abstract}
This article deals with the underlining aspects of Othering within the genocidal process of the Armenian genocide. It will emphasize that Othering is closely related to another process called Selfing, which gives an insight on the genocidal behavior of perpetrators. The article tries to combine these analytical processes with physical actions, and will thereby argue that these physical actions do not stand by themselves, but are indeed cultural expressions of Othering and Selfing; and that these processes are therefore not mere social imagnaire or abstract notions, but physical and thereby observable actions that gives an insight in genocidal intent. These abstract notions or cultural expressions of Othering and Selfing, which by themselves again will be expressed in the enormity of violence and the different dimensions of violence, have the underlining message that one can only solidify a "Self" by destroying the "Other" in all its mechanisms: cultural, social and physical.
\end{abstract}

Keywords: genocidal process, anthropology of violence, Othering, Selfing, identification processes, genocidal intent, Armenian genocide, social imaginaire, symbolism of violence

\section{Introduction: From the Abstract to the Concrete}

Othering is considered a key element within the genocidal process. Alexander Hinton distinguishes between "essentializing Others" and "annihilating Others," where essentializing Others is creating dichotomies where Others are considered filthy, impure even animalistic, and are henceforth symbolically essentially different and separate from the in-group. Annihilating Others is the literal and physical destruction of the out-group. ${ }^{1}$ Between these two processes we also have social destruction: the social deprivation and destruction of social and cultural indicators of the group that has been targeted. What is of importance here is that a dominant culture group, facing a social and political crisis, looks inward to establish a new sense of Self by inventing an Other. ${ }^{2}$ Dichotomies are created. Images are created, where the Other has no further linkage with main dominant culture and can therefore be severed. This implies that genocide is not born out of feelings of superiority, but quite the contrary, of feelings of inferiority. The sense of self-superiority is only projected on the persecuted group. ${ }^{3}$ The dominant culture group becomes, as it were, "predatory." ${ }^{4}$ It feels itself targeted. By looking inwards in smaller and smaller circles, these Others become an internal threat that has to be cleansed and purified. It is only through this purification process and destruction, and eliminating within this a metaphorical and internal threat, that the "new identity" can exist. ${ }^{5}$

Jacques Sémelin emphasises that these identity crisis "are mainly born out of a mental process." 6 That both the new identity and the internal threat are culturally and socially created myths. The notion of social and physical destructiveness lies, in his opinion, in the sociale imaginaire ${ }^{7}$ : a complex network of ideas, imagery, values and symbols. It is here where the genocidal process starts. Not in the acts, but in thoughts and ideas, especially ideas where identity is at the basis, so that "identity supplies the framework within which the process of violence will take shape." ${ }^{8}$ Genocide is therefore not only a physical warfare, but also symbolic and mythological warfare. It is war aimed at the destruction of identities for self preservation and self-existence.

Even though this gives us a starting point to understand the beginning of the genocidal process and how Others are essentialized as a threat, ${ }^{9}$ or dehumanized to such an extent that they are placed outside the realm of humanity, ${ }^{10}$ it does not explain how the sociale imaginaire becomes physical acts. This is a gulf that Claude Lanzmann considered the distance between "the desire to kill and the act itself."11 It is this gulf that I am interested in. How does this sociale imaginaire, which is mythological, abstract and intangible, become a physical act? How come specific target groups falls victim to willing executioners?

Even though there are a myriad of answers to the last question-economic motivations, jealousy, local feuds-my focus will be on the reconstruction of identity. Building on Gerd 
Baumann's concept of grammatical structures, I will first argue that within Othering there is also a process of Selfing. Secondly, I argue that this process does not occur in exceptional circumstances, but is indeed a common day identification practice. Thirdly, this means that the imagery and the ideas used are not in themselves new ideas, but old ones remanufactured. And, fourthly, I argue, there is physicality embedded in Othering that becomes more overtly present during warfare in general, and genocide in particular.

Rather than criticizing the current theories of Othering, this article attempts to add another dimension to an already complicated and abstract mechanism that, hopefully, will make Othering more tangible and visible by using the Armenian genocide as a case-study. My argument is that the social imaginiaire, which is at the heart of the genocidal process, becomes solidified in increasingly physical acts, which Ervin Staub considers "the continuum of destruction."12 This solidification process has only one aim: to create a "new Self." More over, this solidification process, as I will argue, bridges the gulf which Claude Lanzmann referred to as "the desire to kill and the act itself." Understood in such terms, we will see that cultural genocide and cultural destruction are actually extensive parts of the genocidal process, and are not a specific category by themselves, or a dichotomy of the genocide definition. Cultural destruction is one way, in a myriad of ways, to destroy the Other. Genocide is from this point of view not necessarily a war against a specific targeted group, but a war against identity (a symbolic notion) from which a specific targeted group is derived.

The Armenian genocide is an ideal case study to examine the theory of grammatical structures because in essence the genocide was based on a national, and not overtly religious, ethnic, or even racial ideology. Its ideology was based on citizenship, land, mythology and geographic settings and not vague notions as ethnicity or racial differences in blood. The leaders of the Commitee of Unification and Progress (CUP) and the three Pasha's (leaders) that ruled the Ottoman Empire from 1913 onward, were highly secular and only used religion to mobilize citizens. If we use the same mechanisms of Othering and Selfing and place them within an ethnic genocide, which is from an anthropological point of view a problematic one-for ethnicity is based on cultural notions and belief systems which are in essence always fluid and in a state of flux ${ }^{13}$-it would be interesting to see how these mechanisms of Othering and Selfing will be solidified. Or to state it differently: which connotations the perpetrators will attach to themselves and to the Others, for this will say a lot how they will define their ethnic identity, and show how the genocidal violence will develop.

For in the end, using Baumann, the same mechanisms of Othering and Selfing will be at play. And here also lies, in my opinion, the powerful message of Baumann: do not focus on identities, but on identification processes. "In replacing the word 'identities' with the word 'identification' ... we have taken a liberating analytical step." ${ }^{14}$ These processes never stop. They do not occur only in highly political situations or settings, but are indeed common identification practices that people use on a day-to-day basis. It is during genocide that one of these identification processes, or grammars, as Baumann called them, will become genocidal. It will become the primary mechanism in which people will try to create a cohesive sense of Self.

It's important to notice, that in here I differ with the interpretation, and further more, the implementation of these identification grammars from Baumann himself. Baumann states that genocide occurs when all forms of identification processes disintegrate. ${ }^{15} \mathrm{I}$ do not think that they do, but rather that one process becomes more prominent and violent than other identification processes, with only one goal: to solidify the Self. This is important, for if we can decipher the cultural expressions and symbolisms behind the violence-either if this violence is aimed at cultural destruction and/or physical destruction - we can decipher the ideology behind the violence (may this be racial, religious, national or ethnical), and we can show the genocidal intent within the acts of violence itself. The violence becomes the vehicle, so to speak, in which we can trace back the intentions, but also the mental framework of the perpetrators.

\section{The Process of Othering: A Common Day Practice}

Gerd Baumann's The Multicultural Riddle deals with the contextual nature of identity or, in fact, identities. ${ }^{16}$ He claims that individuals adapt different identities throughout the day according to the situation that an individual is in. He gives the example of a fictional office worker who 
uses several identities in a single day. With every person with whom he interacts, he tries to find mutual characteristics and taps, depending on the context, various symbols ranging from religious identities to geographical and class identities. With every step his identity is being determined by the context and forms, both for himself and the person he is interacting with, a new framework of familiarity. ${ }^{17}$ Individuals therefore do not abide by one categorical identity. They do not see themselves solely as a national, ethnical, racial or religious person. Instead, they also use kinship, class, professional titles, gender, or many others, as categorical identities that are adaptable within a given situation. Individuals are agents who choose their identities within a context. ${ }^{18}$ Baumann therefore argues that we should not study the "Turks in Berlin" and "the Sikhs in New York," but the process of identification itself. ${ }^{19}$

In Grammars of Identity, Baumann and Andre Gingrich, provide a structural answer to Baumann's own question how identities are created or how we should study these processes. ${ }^{20}$ According to Baumann, we can divide the identification processes in three different dimensions or grammars: "baby-grammar," "segmentation," and "encompassment." ${ }^{21}$ The focus in my article will be on baby-grammar for this grammar is, as I will argue, central in the genocidal process. ${ }^{22}$ Babygrammar, as the word already suggests, is a primary form of identification and can be interpreted as a cultural language where groups distinguish themselves in a terminology of us versus them. The in-group connects both positive and negative connotations to the out-group on several levels. It is especially during moments in crisis and moments which Abram de Swaan calls dyscivilisation ${ }^{23}$ that baby-grammar, as an identification process becomes more prominent and aggressive. ${ }^{24}$ The mechanism of baby-grammar does not only include Othering, but more importantly also Selfing as shown in the underneath scheme: ${ }^{25}$

Table 1: The Grammar of Oriantalization or Reverse Mirror-Imaging

\begin{tabular}{|c|c|}
\hline $\begin{array}{cl}\text { Occident Positive } \\
\text { - } & \text { rational } \\
\text { - } & \text { enlightened } \\
\text { - } & \text { technological }\end{array}$ & $\begin{array}{cl}\text { Orient } & \text { Negative } \\
\text { - } & \text { irrational } \\
\text { - } & \text { superstitious } \\
\text { - } & \text { backward }\end{array}$ \\
\hline $\begin{aligned} & \text { Occident Negative } \\
& \text { - } \text { calculating } \\
& \text { - } \text { sober } \\
& \text { - } \text { materialist }\end{aligned}$ & $\begin{array}{cl}\text { Orient Positive } \\
\text { - } & \text { spontaneous } \\
\text { - } & \text { luxuriant } \\
\text { - } & \text { mystical }\end{array}$ \\
\hline
\end{tabular}

The analytical importance of this approach is that Othering, or baby-grammar, is always linked with reverse mirroring. It is a dialectic process. Each time we attach a connotation to the Other, we are in essence creating an imaginary Self. If we, for example, perceive the Other as spontaneous, we are implying that we think of ourselves as calculating (negative self-connotation). If we think of the Other as backwards, then we consider ourselves progressive or technologically advanced (positive self-connotation). We do not only do this during a crisis, but continuously. It is through this process of mirroring where we draw fictitious lines between groups. According to Baumann all the grammatical structures of identification unravels through the genocidal process:

If the three grammars are truly useful in distinguishing the different starting-points and consequences of selfings- and otherings, then we must look for cases in which our three grammars hypothesis can pre-specify its own criteria of falsification and defeat. Everyone knows such examples, and they are easy to find under key words such as genocide, ethnocide, political, racial or religious extermination or annihilation. Each of these spells a breakdown of all three grammars and a return to the anti-grammar of: "we are good, so they are bad" with the genocidal conclusion: "we must live, so they must die." ${ }^{26}$

By placing genocide as a form of anti-grammar, however, we are placing genocidal behavior outside the identification process. Genocide becomes something primordial: disconnected from day-to-day 
forms of identification. By doing so, we disregard the fact that ideas of ourselves and Others spring from the same day-to-day identification processes even during genocide, and that Othering and Selfing is of importance within the genocidal continuum. During the genocidal process, and during moments of crisis and decivilization, baby-grammar does not disappear, but becomes the central form of grammar where ideas of Self are established. In this sense we are, within the genocidal process, not only essentializing Others, but also creating an essentializing Self. There is no antigrammar. The baby-grammar enhances increasingly the negative connotations of Others and the positive connotations of ourselves.

Identity entrepreneurs are of extreme importance in this process. ${ }^{27}$ They are the actors who forge, often based on existing ideologies or existing physical and social scientific theories, a narrative of the new Self. That this new Self is not new in the most narrow interpretation of the word-but is a reconstruction based on existing identities, imagery, mental frameworks, ideologies and scientific theories-makes the role of identity entrepreneurs that much more important. The narrative of the new Self is often based on loose and selective populist readings of newspapers and magazines, literature, popular theories, and folklore. Yet these identity myths are powerful partly because they are built on already existing national themes and images, and therefore familiar, and partly because the so-called scientific basis gives the reconstructed ideas, and the (new) political elite, enough ideological weight for implementation. It gives the illusion, as it were, that the narrative of the new Self is grounded, that the new Self naturally exists. They use baby-grammar to the fullest extent. They continuously mirror themselves to Others within society. First they will mirror themselves to the old elite, then to external enemies, and then to the so-called internal enemies. An analysis of Othering therefore should start with identity entrepreneurs.

\section{A Deeper Analysis in Practice: The Building of Turkish Nationalism and the Pathological Fixation on Identity}

Ziya Gökalp was one of the main identity entrepreneurs of the Turkish National identity. He is also one of the most controversial. Some consider him the intellectual mastermind of the Armenian genocide, while others celebrate his contribution to the current Turkish identity after $1923 .{ }^{28}$ Gökalp was born in 1876 in Diyarbakir and was one of the founders of the CUP. He was intellectually influenced by Spencer and Durkheim and sought a way to combine the Eastern ideology of the Ottoman Empire and the Western canon of thought. ${ }^{29}$ Uriel Heyd concludes that the writings of Gökalp illustrate the major inner problems of modern Turkish nationalism: "of how to regain national self-respect and self-confidence which had been so deeply shaken by the continues decline of the Ottoman power and prestige vis-à-vis the West." 30

Already before the first coup in 1908, the Pan-Islam ideology, which envisioned a Great nation of Islam, was questioned. Could the Ottoman Empire keep expanding? According to intellectual Yusuf Akçura, who published an influential article in 1904 called "Three Types of Policies" this was impossible. He contrasted the Islamism with Turkism and argued "that Islamism was doomed to failure and that only Turkism had a chance of political success ... Ethnic Turkish people living in the Caucasus, Crimea and Central Asia had to be liberated from Russian rule." 31 The Ottoman Empire should not focus on a Great Nation of Islam, therefore, but on its Turkish ethnic people.

What makes this article important is that it shows openly that the Ottoman intelligentsia were looking inward for explanations for the Ottoman decline. It also shows openly that the West and Russia were seen as great enemies (as international Others) and that only an expansion of the Ottoman Empire could answer these international threats. Or, to phrase it differently, the Ottoman ideology and identity had to be reconfigured. The Pan-Islam could no longer be its basis. If the focus of identity changed, the article suggests, the Ottoman Empire could be restored to its former grandeur.

In this article we see an expression of the threat of the psychological Self. This Self is threatened by the Great Powers in Europe, but also internally by the Pan-Islam ideology. We also see how this threat can be lifted, by reformulating the Ottoman identity and by regaining the former stature of the Ottoman Empire. This threat is not lifted by reconfiguring the borders or stopping the expansion policies. Rather, the Ottoman self-concept can only be saved when the Empire grows. Gökalp was undoubtedly influenced by this article and, as the intellectual and ideological founder 
of the CUP, he was very much aware that "the Young Turk Revolution of 1908 affected the politics of the Ottoman Empire and that new values had to be created in all spheres of national life." ${ }^{32}$ In many of his writings he therefore tried to distance himself from the former elite and intelligentsia:

There is in our country a class, the so-called Levantines and Cosmopolitans, who try to adopt the aesthetic, moral, philosophical tastes, and entire customs, ceremonies and behaviour of the West rather than its scientific methods and industrial techniques. That is, they try erroneously to imitate the cultures of other nations under the name of civilization. ${ }^{33}$

What is important in this quote is that he creates a difference between the old Ottoman intelligentsia and the new intelligentsia, by focusing on what he sees as the neglected so called Turkish culture. As Uriel Heyd's analysis, "he wanted his countryman to be rooted first of all in Turkish culture and only afterwards to adapt Western civilization." ${ }^{34}$

Just like Akçura, Gökalp looked inward on restructuring identity. However, in contrast with Akçura, Gökalp did not dismiss Pan-Islam outright (even though he was critical of the old elite and distanted himself from the Pan-Islam ideology), but implicitly sought a synergy of the Pan-Islamism and a new Turkish identity. It is therefore, from an anthropological point of view, important to understand that he did not create new concepts or new cultural frameworks, but reused, rephrased, and rearranged old ones. His vision of the Turkish National identity was, in fact, based on the Pan-Islam ideology of the old Ottoman Empire and (especially in the beginning of his writings) on the Islamic tradition of a fraternity and equality of believers. This changed in the course of the political developments between 1908 and 1913. Where he first envisioned a multinational State with different communities and separate nationalities, he afterwards concluded that "only a State consisting of one nation can exist." ${ }^{35}$ The binding factor was Islam. He considered "Islam as the foundation of the Turkish culture." 36

To understand his approach on culture, we have to take a look at his ideas which were inspired by Durkheim. To Durkheim society was an entity, with its own collective conscious. ${ }^{37}$ Each society had its own history, its own trajectory and its own functions. The aim of society was social cohesion. Gökalp adapted these ideas. To him society passed historically through several stages, from a) primitive or tribal to b) a society based on ethnical affinity, to c) a society with a common religion, to finally d) a society united by culture. It is the cultural heritage rather than political will or affiliation that builds a nation. Gökalp definition of a nation is therefore: "a society consisting of people who speak the same language, have had the same education and are united in their religious, moral and aesthetic ideals." ${ }^{38}$ Gökalp therefore makes religion a basic aspect of culture, a primordial phase of culture, and a first step in society's progression.

We see in Gökalp's intellectual thoughts, therefore, a primordial approach, where culture encapsulates all the previous steps. This is a very important emphasis and difference with the PanIslam. Where in Pan-Islam a great nation of Islam was envisioned, this religion was not necessarily primordial. For this reason, different religions could co-exist side by side. In the Pan-Turkish or later Pan-Turan ideology, however, this was impossible. Religion was a basic feature of the Turkish national and ethnic identity. When a great Turkish national state was envisioned, this excluded non-Muslims. ${ }^{39}$ We see this returning in some of his early writings. In one of his essays, Gökalp writes:

that non-Muslim communities had no part of the political life of the Empire and were exempt from military service and that they therefore could concentrate their attention on their economic interests and, thanks to the large measure of autonomy granted to them by the Turks, on the development of their social life. ${ }^{40}$

What is interesting in this statement is the exclusive role he gives to non-Muslims in society. NonMuslims were not burdened by political responsibilities and could therefore pursue economic goals. And, he hereby immediately contextualizes the prosperous position of Christian minorities in some villages and provinces, and combines this with their lack of political commitment. This status quo was tolerated (through aman in the Pan-Islam ideology and the millet-system) by the 
Ottomans. Non-Muslims were therefore not only outside society, they were also parasitic and it was the old Ottoman intelligentsia that had let this happen.

In the above statement of Gökalp we see identity played out on several levels. First he creates a schism with the old Ottoman intelligentsia and the new Ottoman intelligentsia; second he places the Turks in opposition of the Non-Muslims and, by doing so, intertwines Turkism with Islamism (contrary to Akçura). The Turk is furthermore burdened with the political future of society, while the non-Muslim is not. The non-Muslim is therefore not a part of the political entity. Here again we see the threat of the psychological Self; a Self that was not only endangered by external enemies, but also by the old Ottoman intelligentsia and by other groups who had created a home within the Ottoman Empire. The object of Turkism was for Gökalp "to seek the (Turkish) national culture (milî harsi aramak), to bring to light what was hidden in the soul of the nation." ${ }^{41}$ The individual was in the ideological framework of Gökalp subordinate to the State. This is a theme we can find in his poetry:

What is duty? A voice that comes down from the throne of God.

Reverberating the consciousness of my nation.

I am a soldier, it is my commander,

I obey without a question all its orders

With closed eyes

I carry out my duty. ${ }^{42}$

While the crisis between 1908 and 1913 intensified, nationalism deepened. In 1911, during a Congress, the CUP came with the following statement:

In our opinion, it is the aim of the Committee of Union and Progress to establish a united and progressive Ottomanism ... The Committee of Union and Progress considers the Islam the basis of Ottomanism and attributes the existence to this spiritual force. ${ }^{43}$

Here we see how the ideas of Gökalp, and his ideological framework, become the central piece of the new CUP policy. Embedded within this statement, there is an element of a self-fulfilling prophecy. By stating and restating, through writings, policies, laws and decrees, that the problems of the Ottoman Empire lie with the minorities within the State and the enemies outside the State, the minorities in extent become a real threat as identity is reshaped to counter post an imaginary Other.

An article published on the $4^{\text {th }}$ of August 1911 in the periodical Genç Kalemler, after the Italian invasion of Tripoli, claimed that the Europeans' goal was "to swallow us." The article went on to claim that the Europeans "were crushing the peoples in the East, who trampled the humanity of the East underfoot, and who engaged in civilized brigandage which was anything but compassionate and merciful, and which desired to imprison and curse all who were not like themselves." ${ }^{44}$ This article demonstrates how the fear of the physical and psychological Selves increases, and also how the Ottomans use baby-grammar to define Europeans as inhuman and uncompassionate.

The images that Ottoman nationalists used after 1908 became highly pathological, in the sense that they did not come from a positive self-image, but from a negative self-image built upon images of victimization. First, as the work of Gökalp shows, the Turks are victims of the old Ottoman elite (the Ottoman Other). Secondly, they are victims of the inhuman and uncompassionate Europeans (the international Other). And, thirdly, they are the victims of minorities within (the internal Other), who had become prosperous in the old millet-system but did not carry any political responsibility. In each step of the political crisis, Ottoman nationalists can be seen trying to alleviate these three threats to the psychological Self by attaching negative connotations to the different categories of Others (Ottoman, international or internal) and, at the same time, bloating and expanding their own self-image and self-esteem by a false sense of superiority.

The fragility of the self image became crucial during the Balkan wars, where the loss of European territory and possessions had devastating effects. The dream of a rejuvenated and great Ottoman empire shattered. The war became a national shame, as the Ottomans felt that they no longer played a role within the International and European arena. This defeat was handled in the same way as the whole ideological crisis of the Ottoman Empire between 1908 and 1914 
was handled: by turning inward, essentializing Others, and essentializing the Self. This becomes obvious in the poem Esnaf Destam which Gökalp wrote after the Balkan wars:

We were defeated because we were so backward To take revenge, we shall adopt the enemy's science We shall learn his skill, steal his methods

On progress we will set our heart

We shall skip five hundred years And not stand still. Little time is left. ${ }^{45}$

In this poem we see the victimization and the fragile self-concept-the Ottomans were backwards compared to the Europeans. We also see, after the first line, that this victimization is not a source of introspection. To the contrary, the focus and emphasis is on revenge, on taking a step forwardeven five hundred years. There is a sense of threat and urgency in this poem, as if the Ottoman is at the point of being obliterated if it does not respond quickly to the threats. The aim is to destroy the Other before it destroys you. Backwards is juxtaposed with an internal superiority: the Ottoman can skip five hundred years.

The threat of the psychological Self is often repeated by the perpetrators of genocidal violence. Tone Bringa states (referring to Roger Cohen) that genocide was the most overused word in Milošević's vocabulary. Milošević' kept repeating the atrocities that were committed against the Serbians during the Second World War. The culprits were poturice; "those who had become Turks." (Those who converted to the Islam.) They were seen as internal enemies and, in some contexts, poturice was even a synonym for "traitor." 46 Similarly, Christopher C. Taylor points out that before the Rwanda genocide Tutsi's were depicted as invaders from Ethiopia. Tutsi's were intelligent (hamite) invaders, who conquered the slow-witted (bantu) Hutu's. ${ }^{47}$ The massacres on Hutu's in Burundi in (1972) were used as a political example of what the Tutsis, if they had the chance, were capable of doing. ${ }^{48}$ The larger point is that in these narratives there is an expression and articulation of a need for a preemptive strike. The enemy from within should be stopped before it engulfs, destroys or even, to paraphrase the author in Genç Kalemler, "swallows" the dominant culture.

The Self is in an immediate and urgent danger and can only strike outward. This is worded by Gökalp in one of his writings, right before the First World War: "The enemy's country shall be laid to waste; Turkey shall grow into Turan with haste." ${ }^{\prime 9}$ The emphasis of course, in these sentences, is on Turan; the great Turkish Empire. In the narratives of the CUP leaders there was no longer a difference between the European Other (the external) and the Christian Other (the enemy within); the latter was the extension of the first. This is best shown by a statement Talaat made to Ambassador Morgenthau, later quoted in Ambassador Morgenthau's Story in 1918, after Talaat had heard of the massacres on the Armenians:

These different blocs in the Turkish Empire ... always conspired against Turkey; because of the hostility of these native peoples, Turkey has lost province after province - Greece, Serbia, Rumania, Bulgaria. Bosnia Herzigovina, Egypt and Tripoli. In this way, the Turkish Empire has dwindled almost to nothing. ${ }^{50}$

In this statement we clearly see that the Christian minorities were held responsible for the great losses of the Ottoman Empire. This is further exemplified by a statement of diplomat Galip Söylemezoğlu in his memoirs:

A number of crimes were perpetrated during the war ... These crimes occurred for a number of reasons ... I only remember that 350000 Muslims were murdered during the Balkan War. ${ }^{51}$

Here we see how the Balkan Wars legitimized the violence against the Christians. This violence was for survival. It was to purify the nation-state from foreign elements. These foreign elements were at this point in the process, completely dehumanized. They were no longer human beings, or 
identities, they were, to quote Kuşçubaşi Eşref, who played a vital role in the cleansings and was a gendarme in the Special Organization: "internal tumors that needed to be cleaned." ${ }^{2}$ Here we see the baby-grammar in the most direct form. Christian minorities were no longer seen as humans, they were tumors collaborating with the external enemy and therefore had to be murdered. But how can this sociale imaginaire become physical acts? How can thoughts turn fatal? To understand this we have to look at how violence progresses.

\section{From Ideology to Action}

Both Arthur Kleinman and Nancy Scheper-Hughes argue that there are everyday forms of violence. Scheper-Hughes even considers that genocidal tendencies are an endemic feature of modernity. ${ }^{53}$ To her peace-time crimes, like inequality, social sentiments and institutions that support inequality can erupt in genocidal violence. Even though I think that this approach blurs the exceptional nature of genocide, it does place violence in a broader context. Violence is not only physical, but also symbolic. Stigmatising individuals, excluding them from social and political bodies can indeed be considered as violent acts.

We have to keep in mind that the ideology that Gökalp manufactured was not entirely new; they were not new ideas created outside the habitus of the Ottoman culture. In many ways they were an extension of the already existing culture and ideology. They only magnified and rephrased other aspects. Inequality and discrimination were not unknown to the old Ottoman hierarchical structure, they were an integral part of it. It is important to underline this for it explains that the perpetrators of genocide didn't had to learn and internalize new cultural constructs and concepts, but only different emphasises of old concepts. By this the social imagery of Others is not that unfamiliar. When it is used in propaganda, and made available to a greater audience, Sémelin warns us that we should not approach propaganda only as a technical tool. Propaganda is first and utmost a "universe of meaning for all." ${ }^{44}$ What Sémelin implies by this is, is that propaganda is not only a mechanism to persuade or indoctrinate a population, but that there is a more dialectic relationship where the populous are using the propaganda (and therefore also the new concepts) to give meaning and direction to their lives. They do not follow the power holders blindly. The power holders are answering the fears and insecurities of day to day experiences.

Kai Ambos, ${ }^{55}$ as well as Ugur Üngör and Mehmet Polatel, ${ }^{56}$ therefore distinguish three different levels of perpetrators: high level perpetrators, mid level perpetrators and low level perpetrators, also considered foot soldiers or in the case of the Armenian genocide civilians and gendarmes. The high level perpetrators create the ideological framework in which genocidal violence gets sanctified. The mid level perpetrators are the bureaucrats; the ones that implements, oversees the laws and decrees and implementations. The low level perpetrators are the ones that commit the violence itself.

My point is that on each level the ideas of Others and Self are to a high extent internalized. This has to do on one hand with the familiarity of the ideas, but also with the implementation and the institutionalization of the ideological framework itself. With each step that an ideological concept gets translated into a law, a decree or an action, the framework becomes as it were tangible. The ideological concepts become concrete. They are no longer imaginary constructs, but physical and symbolic constructs, which become-because they get repeated and translated in physical actsnormalized. We could compare this with the continuum of destruction mentioned by Staub. ${ }^{57}$ One action of institutionalization can lead to psychological changes where further and extreme actions of institutionalizations become normal. The ideas of Others, which are first abstractions and thoughts, slowly get integrated into the state apparatus and by doing so become more real. In this sense the first steps of Turkification, are at the same time the first institutionalized steps where images of Others and Selves are not only vocalized in an ideological framework but also textualized, emphasised, essentialized and confirmed. Within the bureaucratic and state apparatus there is an endless mechanism that recreates (and emphasises) Others as a distinct group over and over again. Through bureaucratic measures the Other becomes an absolute outsider, an institutionalized Other who is no longer part of the nation-state.

Power over the body is of special importance here. It is, in the most literal sense, the ultimate power one has over another. This power goes further than bureaucratic and institutional power; 
it is the power over personhood. ${ }^{58}$ In this sense violence is the ultimate method of making babygrammar physical, tangible, visible. The hegemony of ideas is not just internalized in the minds of perpetrators and even the victimized group, but even more, it becomes (literally) inscribed in the body. It is the ultimate confirmation of the existence of the superior Self. Indeed it is the physical outcome, as I will argue, of reverse mirroring.

\section{Within the Acts of Violence: Baby-grammar as a Physical Expression}

Anton Blok argues that violence, no matter how senseless, always carries a meaning. That violence as a cultural category or construction should be understood in the first place as a symbolic activity and therefore meaningful behaviour. ${ }^{59}$ It is by analyzing violence we can start to establish the cultural intent of the perpetrators.

In the memoirs of Hampartzoum Chitjian, there are clear depictions of the several stages of the genocidal process ${ }^{60}$ In 1912 he observes, as a child, the first stages of symbolic and institutional violence: "From the very beginning our Christian names were changed to secular names by the new teachers. Kasper became Massis and I became Papken." ${ }^{161}$ Here we start to see the first steps of the phases identification, but also in an indirect way classification and symbolization. By changing the students' names it became clear who was and who was not a Turk. However, there is another discourse underneath this action; by changing the name, the Christian name became subordinated to the non-Christian name. The Christians were made an Other.

At the same time the Turkification at schools increased:

Within a few days we slowly realized what their intentions were for us. They began a very deliberate plan to convert us. We were to become Turkified. The very first thing they did was to change our Armenian names into Turkish names ... Next day they demanded we no longer speak Armenian. They insisted we speak only in Turkish. ${ }^{62}$

What we see here are a few very crucial elements. Changing names into secular names is not enough; they have to be changed into Turkish. There is also a refocus on language; not only names became subordinated to the Turkish hegemony, but also the language and even the interpretation of history itself:

Next they started to teach us their Turkish history. We were taught to say in Turkish:

\footnotetext{
"Freedom, Liberty, Fraternity - long live the people

We are Ottoman, we are brothers, our customs are ancient

We must devote our lives as a gift towards our country

We are Ottomans, we are brothers." ${ }^{63}$
}

One had to abide by the new national identity. All Ottomans are brothers, their customs are ancient. Lives should be devoted as a gift to the country. This implies that if one was not an Ottoman (and keep in mind here that definition of Ottoman was more primordial than at the start of the revolution of 1908), one was not a brother and if one did not follow the ancient customs, they were therefore an outsider. What being an Ottoman meant was expressed in the following actions: "The last thing they tried to change was our faith in Christianity. We had to memorize and recite in Turkish: Mohamed is a saint and his teachings are correct." ${ }^{64}$ To be Turkish therefore meant that one had to a) speak the language, b) carry a Turkish name, c) abide to Ottoman interpretation of history, d) follow supposedly ancient customs and e) convert to the Islam. Here we see the theoretical and ideological framework of Gökalp expressed in the modes of (symbolic) violence. In each step the personal identity became subordinated by the Nationalistic identity of the CUP and the Other got more and more institutionalized.

We see from this point onward how the violence increases:

Three weeks later without warning ... three gendarmes entered the Protestant Church before we were taken out to pillage for the day. Without a word they promptly started to 
separate boys according to their physical size and age ... as it turned out, the older boys were separated from the group because they were designated to be killed on that day. The Turks knew the older boys were not going to convert and become Turk and therefore would continue to be a threat. ${ }^{65}$

What makes this eyewitness statement so significant is that the individuals who could not convert, or who were considered too old to convert, were a threat to the Turkish identity. Here we see how the imagined threat of the self-concept is expressed in physical action. Here we also see that identity was the focus of the violence. Older boys that could not convert were killed. It was not necessarily the boys themselves that were being targeted - for the younger boys were kept alivebut the Armenian (and or Christian) identity. The removal of material possessions, as the following eyewitness account shows, is of great importance during the violence:

I saw them go: an endless procession, accompanied by gendarmes, who spurred the crowds on with sticks. Scantily clad, exhausted they dragged on. Elderly women had collapsed from exhaustion, but had to carry on; they did not want to get acquainted with the threatening sticks of the gendarmes. The Turkish do not allow them to carry a single item of clothing or a mule or a goat. All that they possessed was sold for next to nothing. ${ }^{66}$

If we consider the economical position of Christian minorities in the Ottoman Empire, this violence had a strong symbolic nature. The social status of Christians was often based on their economical position. Taking away material possession therefore is not only taking away their wealth, but also their social status and economic identity. At the same time Christian Churches (another important local identity indicator) were being destroyed:

... the Turkish government, the Mulhallemi, and the Kurds were openly encouraged to set their whole plan in action with respect to disposing of all the [East and West] Syriacs in the area. They surrounded Midyat from all sides in vast numbers and started indiscriminate killings of the Syriacs, destroying their houses, churches, monasteries, and palaces. ${ }^{67}$

What makes this statement important is that the killing itself was not enough. Churches and houses also had to be destroyed, as if the landscape itself had to be cleansed (purified) from Christian elements. Here we see that not just people, but more importantly, identity was being targeted. When houses were not destroyed, they were repossessed by Muslims:

Oh, my Der baba, wherever we went, they threw us out. Through the windows we would enter the houses left empty by Armenians and sleep there at night, but now those houses are filled with Turkish refugees. ${ }^{68}$

What makes this act so symbolic is that the Turkish refugees are in fact Muslim refugees from the Balkan wars. As Üngör points out, the deportations went both ways. ${ }^{69}$ The Christian minorities were deported outwards, while the Muslim refugees from the Balkan were deported inwards. The Armenian and Syriac houses were to be used as accommodation for the homeless refugees. If we combine this with the importance, that the Balkan wars had, on the identity crisis of the Ottoman Empire, the movement of Muslim refugees was not only economically motivated, but also symbolic. The Muslims were literally claiming possession of their land. It is in this point in the memoires and eyewitness account that the details of the atrocities become more graphic, but also in the same instant more fragmented and circumventive. The most horrifying scenes are described, but often disassociated. There is a reason for this and this has to do with the explicit nature of the violence itself. It is impossible to capture these horrors in texts; violence goes beyond words and meaning; language doesn't translate what aspired. Michael Taussig speaks of "space of death;"70 Sasanka Perera calls it the "shadow of death." ${ }^{71}$ Regardless, it is the moment that culture unravels, that all cultural and social meanings within the acts of violence are lost: 
space of death is pre-eminently a space of transformation: through experience of coming close to death there will be a more vivid sense of life; through fear there can come not only growth in self-consciousness but also fragmentation, then loss of self conforming to authority. ${ }^{72}$

The space of death is a moment during the experience of violence, where there are no words, where culture disintegrates, where the victim is very much aware of his physical being and the loss of control over his or her own self-determination and destiny. At that moment the victim is nothing more than blood, brains and bones, ${ }^{73}$ a physical vessel that can be tortured or killed to the likings of the aggressors. Language cannot fill this experiential space. There are no cultural frameworks that can give meaning, definition or direction; there is only the experience of fear and the realization of death itself.

This is also the moment where violence in the most physical form gets inscribed in the mind and in the (social) body of the victimized group. This is the experience that direct survivors cannot convey; where only loose images get communicated; often non-discursive and through silence. At the same instant however, this moment is symbolically important; especially if we put it in the continuum of the identity crisis of the perpetrators. It is here where the dominance of the perpetrator is the most visible and acute; it is here where the experiential world of the aggressor in fact becomes the experiential world of the victim; where the Other is not just imaginary in the social fabric of the perpetrators world, but where the Other is physically constructed.

Henry Riggs, an American missionary, speaks of the horror of starvation, near Harpoot, where caravan routes converged and the Ottomans created a camp:

As we reached the edge of the camp, an unforgettable scene occurred. Seeing us coming, the people thronged about us, each trying to get within reach, and all crying out with the pitiful fierceness of starvation, "Bread! Bread! Bread!" Each one was thinking of their own hunger, or of her children, so they jostled each other as they surged about us ... more like starving animals than human beings. ${ }^{74}$

In the above description we see the powerlessness of the narrator. We also see something else, something that is not easily captured in words: how the experience of starvation, disease and exhaustion disintegrates the collective identity; that only fear survives. People fight for bread. People fight for life. All other identity indicators are stripped away. For those who did not die of disease, exhaustion or starvation, there was often a worse fate:

Many caravans arrived at Midyat; and they were filled with women and children. They were taken to the mosque's yard. The yard would become overcrowded. To reduce the number of hostages, the Turkish forces gathered the boys, around 500-600. They told them to lie down, face down. Then they took some thick sticks and beat them on the head. Then some 40 to 50 Turkish soldiers riding horses rode back and forth over the boys' heads until they died. ${ }^{75}$

This violence carries multiple symbols. The public display of violence emphasis the inferiority of the Christian victims to the dominant hegemony. It also meant to depersonalize the victims; to make them puppets in the hands of the power holders. At the same time the disregard in which the bodies were spread out and displayed, also carried a warning for spectators and bystanders:

[the corpses] were laid in such a position as to expose their persons to the ridicule of passers by, and on the abdomen of each was cast a large stone. They had evidently been murdered there at the noon hour and then the brutal guards had stopped to leave behind them the signs not only of violence but of mockery and insult. ${ }^{76}$

Humiliation in life had to be perpetuated after death. The mockery and inferiority had to inscribed literally in the physical but also in the social and even geographical body; the deaths had to be visible, and where they were invisible, there were often sanitarian and not humanitarian reasons to do so: 
The corpses of tens of thousands of Armenians had been buried - not as the sacred obligation finally due to all mankind, civilized or savage, since prehistoric times. Rather, these corpses had been buried by Muslim labourers sent by the government simply to "cleanse the environment" of the pollution caused by tens of thousand of rotten and decomposed bodies. ${ }^{77}$

In the above statement the victims are not only placed outside the new Turkish nation-state, but also outside time. They weren't given the same rights of the prehistoric ancestors of all human kind.

There is another dimension of the violence that we have to address, and which has only been implicitly present in the above statements and this is the sexualisation of violence. One eyewitness account speaks of "raping women and young girls in front of everybody" and of "pregnant women being killed after their babies were taken from their bellies." ${ }^{178}$ Others describe how girls were taken to harems or were raped before they were killed. There was also violence aimed at genitals: "The male corpses are in many cases hideously mutilated (sexual organs cut off, and so on), the female corpses are ripped open." ${ }^{\prime 79}$ Or, as Danielyan writes, "In Dilman ... we saw the traces of boundless brutality, glowing skewers were run through genitals of both women and men, and they were put to death this way." ${ }^{\prime 80}$ The sexualisation is a reoccurring theme in all warfare, but more specifically present during ethnic cleansings. ${ }^{81}$ Some of this violence is considered opportunistic and other strategic, meaning that sexual violence occurs when "an armed group believes it to be an effective form of terror against or punishment of a targeted group." 82 There is of course another dimension of sexual violence, and this is the symbolic dimension. Raping a victim is the ultimate physical dominance of the aggressor and the one that is subordinated. Raping is putting shame on women's bodies, and by doing so also on communities. It is a way to differentiate the dominant cultural group from the Other. ${ }^{83}$ "Women thus become the embodied boundaries of the nation-state." ${ }^{84}$ Controlling women is controlling the reproduction of identity. This does not explain however the mutilation and the removal of men genitals, as the above quote shows. I think that in these instances there is another mechanism of identity-destruction at play; it is the literal deprivation of the gender identity of the victimized group and thereby enhancing the masculinity of the aggressors.

There are other symbolisms. The metaphors where victims resemble animals are the most often used metaphors in the memoirs and eye witness accounts. The use of these metaphors by survivors is of great importance. It shows how they experienced the violence as something inhuman and in some cases animalistic. By killing the Armenians as animals, they were regressed as non-human beings as the following eye-witness account shows:

Then I saw with my own eyes the Turks beating a fellow named Sahag, who had hid under his wife's dress. They were beating him with hammers, axes right in front of me and his wife. He yelled to her to run away, that we are all going to die a "donkey death". ${ }^{85}$

The term "donkey death" was referring to the act of cutting throats. It was a way of killing animals, mostly in ceremonial settings.

If we summarize the symbolism and compare it to the mechanisms of baby-grammar and reverse mirroring we come to an interesting observation. During each step in the continuum of destruction the violence increases and a layer of identity is stripped from the victimized group. First the obvious and primary identity markers, like names (kinship), language, (collective) history and religion were destroyed. Then came the physical destruction and within these acts the violence is symbolic; the victims are concentrated, overpowered, de-gendered, penetrated and in the end dehumanized. Through the act of mirroring the identity layer that is stripped away, confirms at the same instant the identity of the in-group. By destroying the names (kinship), for example, the perpetrators are confirming and solidifying their own kinship and heritage. By destroying the language of the out-group, the perpetrators are confirming the superiority of their own language. By making the collective history of the out-group subordinated to the nationalistic tale, the perpetrators are actually confirming their own history. By destroying the religion, the perpetrators are confirming the superiority of their own religion. Within each step of the violence, the fixation on identity for the in-group, is symbolically resolved, ending with the most gruesome acts by 
which the in-group confirms its power over reproduction, masculinity and humanity over the outgroup.

Arjun Appadurai ${ }^{86}$ emphasises the great importance of Death. Killing is an act where the construction of "fake" identities demands the brutal "creation" of real people through violence: "violent action can become one means of satisfying one's sense of one's categorical self." ${ }^{77}$ In this I agree with Appadurai. I think however that this process starts before the killing. It is not only death that solidifies the categorical self, but each step of the violence is solidifying a layer of identity in the minds of the perpetrator.

Vamik Volkan ${ }^{88}$ describes the development of individual identity to a group identity. His approach is psycho-analytical. He describes how an individual first separates a subject from object and establishes his ego, which Volkan describes as an "inner sense of sameness." 89 When this ego is constructed, and the individual ages, more layers of identity are absorbed. An individual becomes aware of his gender, his family and eventually his group identity and includes these, into his self-representation. Although it would be too early to hypothesize, it is interesting and thought provoking that within the acts of violence we see a similar process, but then in reverse. First the obvious identity makers (language, names and churches) are destroyed, until the more abstract identities, like gender and humanity, which are to a child more primary, are deprived from the victimized group. By stripping away each layer of identity from the out-group, the ingroup solidifies and establishes its identity and more subconsciously, its own existence.

This is where genocidal violence differs from other acts of collective violence: where warfare is used to meet political goals, political actions are used to repress a population and revolutions are used to overthrow the current hegemony and power, genocidal violence is aimed at destroying an identity. This destruction, from the point of view of the perpetrator at least, has to be complete whether it is aimed at an ethnic, national, cultural, racial or even a political identity. This is the reason why genocide is indiscriminately aimed at civilians and generally includes cultural genocide and ethnic cleansing. The goal of the violence is pure annihilation. Genocide is successful when a specific group no longer exists, or even more than that, if not only the nation-state but also the national history is cleansed from this "foreign element."

\section{Concluding Remarks}

It was my goal in this article to bridge the gulf that Claude Lanzmann considered the distance between "the desire to kill and the act itself." 90 The answer that I provided lies in the grammatical structures of Baumann. Its thereby important to note that a sense of belonging is a primary and basic need for human beings. This belonging can be attached to a family or a tribe, but can also be attached to more abstract notions as religion, ethnicity, race or nationality. This sense of belonging can be so strong, so derivative, that people are willing to kill for it and die to protect it. Baumann deciphers three structures in which identity takes shape. First he states that identities are always in a state of flux and that studying identities themselves are, therefore, analytically speaking, not all-telling or significant. It is interesting to study how people define themselves, but it does not give us any insight in which way people define themselves. He answers this problem, which he considers a "riddle," by not focusing on identities, but on identification processes. His answer is thereby not agency based, but structurally based.

Baumann deciphers three forms of identification processes. One is primordial however, a process he terms baby-grammar. This is one of the basic forms how identities are created. Through the baby-grammar identification process, individuals create dichotomies between themselves and Others. It is my argument that this baby-grammar becomes the primary grammatical structure during the genocidal processes, when more and more negative connotations are attached to Others, to such an extent that they become essentialized and dehumanized, and the dominant culture group establishes a more cohesive sense of Self. This is a cumulative process, similar to the continuum of destruction. The Other, at first, is only constructed in ideologies and the sociale imaginaire. However, the Other becomes more and more tangible through the act of institutionalization. The Other is literally visualized in laws and decrees, through social institutions, until the Other no longer becomes an imaginary Other, but an tangible Other that can be destroyed-a person who can be killed. This is, as I have argued, by studying the Armenian genocide, the bridge between the gulf 
of "the desire to kill and the act itself." On some subconscious level, this grammatical structurewhether motivated to kill by economic gain, or personal jealousy, or any other reason on a micro level-plays an enormous part in the incentives to commit genocide, and also the methods that are used during the killing. To kill a group out of jealousy or economic gain, for example, the group already has to be targeted and dehumanized. To slaughter them like animals and to torture them, shows in the most basic form that they are no longer a part of the dominant culture group.

Through the whole machinery of destruction, we see how a layer of identity of the victimized group is indeed stripped away, to solidify a similar layer into a new image of the Self. Once again, these are subconscious actions, partly because the grammars of Baumann are dayto-day processes. They are not "abnormal" to the perpetrators. The institutionalization of the Other has already taken such a shape, that killing the Other is no longer an abnormal act, but even a communal duty to the dominant culture group. We create our identity without realizing it, over and over again. This is the core of the genocidal process, and also the reason why it is so dangerous and why ordinary men can commit horrendous acts; the processes in which these acts take place, the mechanisms behind the acts, are actually so daily, and grind into society so slowly, that stigmatizing and dehumanizing is normal in our day-to-day behaviour. Baby grammar doesn't become genocidal overnight, it is a normal process which first gets formed, slowly turns aggressive, then gets institutionalized and can then be expressed physically. In here I concur with the analysis of Emike OhnukiTierney and her definition of méconnaissance: actions on a micro level, even inspired by different motivations, confirms the ideological beliefs or belief systems on a macro level ${ }^{91}$. There is a dialectic between micro and macro behaviour, and not a dichotomy, and I believe that the grammatical structure of baby grammar provides us an answer where we as social scientists and social critics can actually see negative- and positive mirroring in its most physical form.

This has certain implications for the study of violence and genocide. First, we can derive meaning from the acts of violence and we can establish the genocidal intent, if we study the whole machinery in which the violence takes shape. Secondly, study genocide from this perspective gives insights into the genocide process that are useful to early warning systems to prevent genocidal acts in the future. From the perspective outlined in this article, the most useful insight for these early warning systems, is to focus on the point when ideologies and ideas of Others are turned into actual laws and decrees. In the end, violence, and the act of violence itself tells a story.

\section{Endnotes}

1 Alexander L. Hinton, "The Dark Side of Modernity: Toward an Anthropology of Genocide," in Annihilating Difference: The Anthropology of Genocide, ed. Alexander L. Hinton (Los Angeles: University of California Press, 2002), 6-12.

2 And even this is a simplification, for in many genocides you see several out-groups.

3 Ervin Staub makes a similar observation: "All human beings strive for a coherent and positive self-concept, a self-definition that provides continuity and guides one's life. Difficult conditions threaten the self-concept as people cannot care for themselves and their families or control the circumstances of their lives." Ervin Staub, The Roots of Evil: The Origins of Genocide and Other Group Violence (Cambridge: Cambridge University Press, 1989), 15.

4 By "predatory" Peter Geschiere is referring to a mechanism, in his study on the identity classification of autochthony, that an identity "can start cannibalizing other identities instead of accepting a pluralist configuration." Peter Geschiere, The Perils of Belonging: Autochthony, Citizenship, and Exclusion in Africa and Europe (Chicago: The University of Chicago Press, 2009), 166.

5 Arjuan Appadurai, "Dead Certainty: Ethnic Violence in the Era of Globalization," Public Culture, 10, 2 (1998): 225-247. http://dx.doi.org/10.1215/08992363-10-2-225

6 Jacques Sémelin, Purify and Destroy: The Political Uses of Massacre and Genocide (London: Hurst and Co, 2007), 9.

7 Ibid., 17.

8 Ibid., 49. 
9 Hinton, "The Dark Side of Modernity," 12-13.

10 Sémelin, Purify and Destroy, 38.

11 Claude Lanzmann, “Les non lieux de la mémoire," in Nouvelle Revue de Psychanalyse, no. 33, 1986, 20.

12 Staub, The Roots of Evil, 17.

13 Gerd Baumann considers ethnicity compared to racial or national ideologies, to an identity based on wine (a cultural and cultivated mixture) instead of blood (a racial ideology). A national identity is based on geography, citizenship and land. See also Gerd Baumann, The Multicultural Riddle: Rethinking National, Ethnic, and Religious Identities (New York: Routledge, 1999), 20-21. The Armenian genocide was a genocide based on a national ideology, because ethnicity and religion were secondary; you could convert to Islam and you could become a Turk. With ethnicity the emphasis lies more with descent, kinship, language, religion-and the emphasis might differ with the mindset of the perpetrators and the target group. This is why anthropologists consider it an identity always in a state of flux, for the perpetrators actually emphasize which element is important. It is not that ethnicity was not present during the Armenian genocide, it was secondary to the national ideology, which also explains the high level of conversion and selling and taking in Armenians at slave markets during the genocidal process. See also the testimony of Harutyun Zakar Martikian in, Verjine Svazlian, The Armenian Genocide, Testimonies of the Eyewiness Survivors (Yerevan: Gitoutyoun Publishing House, 2011), 257. For further study see also: Ara Sarafian, "The Absorption of Armenian Women and Children into Muslim Households as a Structural Component of the Armenian Genocide," in In God's Name: Genocide and Religion in the Twentieth Century, ed. Omer Bartov and Phyllis Mack (New York: Berghan Books, 2001).

14 Ibid.,137.

15 Gerd Bauman, "Grammars of Identity/ Alterity: A Structural Approach," in Grammars of Identity/ Alterity: A Structural Approach, ed. Gerd Baumann and Andre Gingrich (New York: Berghahn Books, 2004), 42.

16 Gerd Baumann, The Multicultural Riddle: Rethinking National, Ethnic, and Religious Identities (New York: Routledge, 1999).

17 Ibid., 85.

18 The agency and structure debate is at the center of Anthropological theory, between the question of how much we do is influenced by capabilities and how much of our behavior is guided by structure. This debate has a long history within Anthropology and there is no clear answer. Historically American Anthropologists, especially in the field of Medical Anthropology, are more agent based, while European Anthropologists lean more towards structure. The current consensus is that both agency and structure determines behavior, but that structure guides agency.

19 Baumann, The Multicultural Riddle, 145.

20 Baumann, "Grammars of Identity/ Alterity."

21 Ibid., 19-27.

22 The segmentation process is a grammatical structure where processes of fission and fusion take place within a group. Fission means the separation of groups from the main group and fusion the merging of these groups at a higher level. Encompassment reflects a process in which a segment of the group is encompassed by another group. See Baumann, "Grammars of Identity/ Alterity." 24-26. See also the books that influenced his ideas: Edward E. Evans-Pritchard, The Nuer: A Description of the Modes of Livelihood and Political Institutions of a Nilotic People (Oxford: Clarendon Press, 1940); Edward Said, Orientalism (New York: Vintage, 1987). Louis Dumont, Homo Hierarchicus: The Caste System and Its Implications (Chicago: University of Chicago Press, 1980).

23 Abram de Swaan, "Dyscivilisation, Mass Extertmination and the State," Theory, Culture and Society 18, 2-3 (2001), 265-276.

24 The decivilization process is opposed to the civilization process as formulated by Norbert Elias. According to Elias, the civilization process is characterized by a constant need for self-regulation due to increasing interdependent relationships among different groups in society. During this particular process values and behavioral patterns of the middle and higher classes interweave with those of other layers of the community. These processes of civilization, however, are accompanied by moments of decivilization: moments in which the interdependent relationships decrease and an interwoven behavioral pattern unravels. Ton Zwaan, Civilisering en Decivilisering: Studies over Staatsvorming en Geweld, Nationalisme en Vervolging (Amsterdam: Boom, 2001).

25 Baumann, “Grammars of Identity/ Alterity," 20.

26 Ibid., 42.

27 Sémelin, Purify and Destroy, 54. 
28 See Uriel Heyd, Foundations of Turkish Nationalism: The Life and Teachings of Ziya Gökalp (London: Luzac \& Company Ltd. and The Harvill Press Ltd, 1950). Also see Taha Parla, The Social and Political Thought of Ziya Gökalp 1876-1924 (Leiden: Brill, 1985).

29 Ayșe Kadioğlu, "The Pathologies of Turkish Republican Laicism," Philosophy and Social Criticism 36, 3-4 (2010): 489-490.

30 Heyd, Foundations of Turkish Nationalism, 170.

31 David Gaunt, Massacres, Resistance, Protectors: Muslim-Christian Relations in Eastern Anatolia During World War I (New Jersey: Gorgias Press, 2006), 50.

32 Heyd, Foundations of Turkish Nationalism, 43.

33 Parla, The Social and Political Thought of Ziya Gökalp 1876-1924, 30.

34 Heyd, Foundations of Turkish Nationalism, 65.

35 Ibid., 131.

36 Ibid., 150.

37 Emile Durkheim, "Religion and Ritual," in Emile Durkheim: Selected Writings, ed. Anthony Giddens (Cambridge: Cambridge University Press, 1887 [1972]).

38 Heyd, Foundations of Turkish Nationalism, 63.

39 This is not to state however that the leaders of the CUP were religious, they were as a matter of fact mostly secular. This was not a religious but an intellectual approach on Islam. We have to separate this. For two major reasons: 1) the Armenian genocide was not a religious genocide. It was a genocide based on nationalism and national sentiment. Religion was politicized and used to mobilize the Turkish population. It is unclear what the role of religion was during the genocide, it had both a catalyst and a tempering effect. 2) And this is another important reason why we should be careful: by placing the Islam now in the centre of the Armenian genocide, were are in fact unconsciously projecting the present day international and political tensions, and the present day notions of extreme Islam onto the old Ottoman Empire and the old Ottoman elite. Islam was for Gökalp mostly an intellectual tool to understand the Turkish identity and society.

40 Heyd, Foundations of Turkish Nationalism, 130.

41 Ibid., 110.

42 Ibid., 124.

43 Taner Akçam, A Shameful Act (New York: Metropolitan Books, 2006), 77.

44 Akçam, A Shameful Act, 81.

45 Heyd, Foundations of Turkish Nationalism, 79.

46 Tone Bringa, “Averted Gaze: Genocide in Bosnia-Herzegovina 1992-1995," in Annihilating Difference: The Anthropology of Genocide, ed. Alexander L. Hinton (Berkeley: University of Press, 2002), 215.

47 Christopher C. Taylor, "The Cultural Face of Terror in the Rwandan Genocide of 1994," in Annihilating Difference: The Anthropology of Genocide, ed. Alexander L. Hinton (Berkeley: University of California Press, 2002).

48 Liisa H. Malkki, Purity and Exile: Violence, Memory and National Cosmology among Hutu Refugees in Tanzania (Chicago: University of Chicago Press, 1995).

49 Akçam, A Shameful Act, 93 or, worded differently, in Heyd, Foundations of Turkish Nationalism, 128.

50 Akçam, A Shameful Act, 92.

51 Ibid., 117.

52 This quote can also be found in, Ben de Yazdim, vol. 5, 1578.

53 Nancy Scheper-Hughes, "A Genealogy of Genocide," Modern Psychoanalysis 28, 2. (2003), 369. See also Arthur Kleinman, "The Violence of Everyday Life: The Multiple Forms and Dynamics of Social Violence," in Violence and Subjectivity, ed. Veena Das, Arthur Kleinman, Mamphela Ramphele, Pamela Reynolds (Los Angeles: University of California Press, 2000).

54 Sémelin, Purify and Destroy,71-72.

55 Kai Ambos, “What Does 'Intent to Destroy' in Genocide Mean?” International Review of the Red Cross, 91, 876 (2009). http://dx.doi.org/10.1017/S1816383110000056

56 Ügur U Üngör and Mehmet Polatel, Confiscation and Destruction: The Young Turks Seizure of Armenian Property (London: Continuum, 2011).

57 Staub, The Roots of Evil, 17. 
58 Michel Foucault, The Will to Knowledge: The History of Sexuality, part 1 (London: Penguin Books, 1976), 143. 59 Anton Blok, "Zinloos en Zinvol Geweld," Amsterdams Sociologisch Tijdschrift 18, 3 (1991), 203.

60 Hampartzoum M. Chitjian, A Hair's Breadth From Death: The Memoirs of Hampartzoum Mardiros Chitjian (London: Taderon Press, 2003).

61 Ibid., 76.

62 Ibid., 100.

63 Ibid., 101.

64 Ibid., 101.

65 Ibid., 104.

66 Translated by the author from "Nederlandsche Comité tot Hulpbetoon aan de Noodlijdende Armeniërs. 1918. Marteling der Armeniërs in Turkije: Naar Berichten van Ooggetuigen." (Haarlem, 1918), 16, 17.

67 Gaunt, Massacres, Resistance, Protectors, 330.

68 Gregory Balakian, Armenian Golgotha (New York: Alfred A. Knopf, 2009), 249.

69 Ügur U Üngör, “Seeing like a Nation-state: Young Turk Social Engineering in Eastern Turkey, 1913-50," Journal of Genocide Research, 10, no. 1. (2008): 15-39. http://dx.doi.org/10.1080/14623520701850278

70 Michael Taussig, Shamanism, Colonialism, and the Wild Man: a Study in Terror and Healing (Chicago: University of Chicago Press, 1987).

71 Sasanka Perera, "Spirit Posessessions and Avenging Ghosts: Stories of Supernatural Activity as Narratives of Terror and Mechanisms of Coping and Remembering," in Remaking a World: Violence, Social Suffering, and Recovery, ed. Veena Das, Arthur Kleinman, Margaret M. Lock, Mamphela Ramphele, and Pamela Reynolds (Los Angeles: University of California Press, 2001).

72 Taussig, Shamanism, Colonialism, and the Wild Man, 7.

73 Mattijs Van de Port, Gypsies, Wars and Other Instances of the Wild: Civilisation and It's Discontents in a Serbian Town (Amsterdam: Amsterdam University Press, 1998), 101-103.

74 Henry H. Riggs, Days of Tragedy in Armenia: Personal Experiences in Harpoot, 1915-1917 (Michigan: Ann Arbor, 1997), 147.

75 Gaunt, Massacres, Resistance, Protectors, 342.

76 Riggs, Days of Tragedy in Armenia, 57, 58.

77 Balakian, Armenian Golgotha, 242.

78 Gaunt, Massacres, Resistance, Protectors, 334.

79 James Bryce and Arnold Toynbee, The Treatment of Armenians in the Ottoman Empire, 1915-1916. Uncensored Edition, ed. by Ara Sarafian (London: Taderon Press, 2000), 23.

80 Eduard Danielyan, The Armenian Genocide of 1884-1922 and the Accountability of the Turkish State (Yerevan, self-published, 2005).

81 Elisabeth J. Wood, "Variation of Sexual Violence during War," Politics and Society 34, 3 (2006), 327. Or Doris Buss, “Rethinking Rape as a Weapon," Feminist Legal Studies 17, 2 (2009), 150.

82 Wood, "Variation of Sexual Violence during War," 331.

83 Sukanya Banerjee, Angana Chatterji, Lubna N. Chaudry, Manali Desai, Saadia Toor, Kamala Visweswaran, "Engendering Violence: Boundaries, Histories, and the Everyday," Cultural Dynamics 16 (2004), 129. http://dx.doi.org/10.1177/0921374004047739

84 Buss "Rethinking Rape as a Weapon," 148.

85 Rouben P. Adalian, “The Armenian Genocide," in: Century of Genocide: Eyewitness Accounts and Critical Views, ed. Samuel Totten, William S. Parsons and Israel W. Charny (New York: Garland Publishing Inc, 1997,) 71-72.

86 Arjuan Appadurai, “Dead Certainty: Ethnic Violence in the Era of Globalization,” (1998).

87 Ibid., 244.

88 Vamik D. Volkan, "Individual and Large-Group Identity: Parallels in Development and Characteristics in Stability and Crisis," Croatian Medical Journal 40, 3 (1999): 458-465. It is interesting that Franco Fornari also makes a link to how an infant conceives his safety, when he tries to explain the psycho-analytical mechanisms of warfare. He states that groups, just like an infant, can get into a "paranoid-schizoid" position, where the infant or group safes itself by destroying the object by which he feels destroyed. Franco Fornari, Psychanalyse de la Situation Atomique (Paris: Gallimard, 1969), 35. 
89 Vamik D. Volkan, "Individual and Large-Group Identity," 459.

90 Claude Lanzmann, “Les non lieux de la mémoire,” 20.

91 She even goes a step further and states that actions on a macro and global, from an ideological point of view, and actions on a local is a wrong dichotomy. By studying the diaries of Kamikaze pilots, she comes to the conclusion that even though the pilots may differ in their ideologies and thoughts, by becoming a Kamikaze pilot and kill citizens they indirectly confirm the state ideology. This is what she considers méconnaissance. Emiko Ohnuki-Thierney, Kamikaze, Cherry Blossoms and Nationalism: The Militarization of Aesthetics in Japanese History (Chicago: The University of Chicago Press, 2002), 2-3, 249. 